\title{
New record of the blunt bladed shrimp Spirontocaris truncata (Caridea: Thoridae) from the Gulf of Alaska
}

\author{
David T. Drumm ${ }^{*}$ and Sean Rohan ${ }^{2}$
}

\begin{abstract}
Background: The blunt bladed shrimp Spirontocaris truncata inhabits sponges and is typically found on subtidal rocky reefs, and is distributed from the Strait of Georgia, British Columbia to Baja California, Mexico at depths of 37 to $92 \mathrm{~m}$.

Results: This paper presents a new record of this species obtained from stomach contents of the Pacific cod, Gadus macrocephalus, from the northern Gulf of Alaska, which extends its distribution range over $1800 \mathrm{~km}$. This is the first record of the species in Alaska.

Conclusions: A large northward range extension was documented for the shrimp Spirontocaris truncata. A clear understanding of the distribution of marine species is a necessary prerequisite for effective monitoring and predictions about future changes to marine ecosystems.
\end{abstract}

Keywords: Alaska, Gulf of Alaska, Thoridae, Spirontocaris, Blunt bladed shrimp

\section{Introduction}

The National Oceanic and Atmospheric Administration's (NOAA) National Marine Fisheries Service (NMFS) has conducted fisheries bottom trawl surveys along contiguous sections of the North American coast in the eastern North Pacific Ocean since the mid-1970s (Pereyra et al., 1978; Gunderson and Sample, 1980) and the surveys provide valuable data and specimens for studying the geographic distributions of a wide variety of marine taxa. The NMFS Alaska Fisheries Science Center (AFSC) conducts surveys on the continental shelf and upper slope to a bottom depth of $1000 \mathrm{~m}$ in the Gulf of Alaska (von Szalay et al., 2010). Recent efforts by NMFS to document the diversity of Alaska's marine invertebrate fauna (Drumm et al., 2013; Drumm et al., in press) have revealed new records for species in the area. A standard practice for AFSC surveys is the collection and identification of fish stomach contents to understand the food habits of commercial fishes.

* Correspondence: ddrumm@ecoanalysts.com

${ }^{1}$ EcoAnalysts, Inc., 1420 S. Blaine Suite 14, Moscow, Idaho 83843, USA

Full list of author information is available at the end of the article
The Thoridae (= Hippolytidae sensu lato in part, see De Grave et al., 2014) is the largest family of marine shrimps in the northeastern Pacific Ocean, containing eight genera and 57 described species (De Grave and Fransen, 2011). Thorid shrimps occur worldwide but are most diverse in cooler waters of the northern hemisphere. The genus Spirontocaris, commonly called 'blade shrimps', is currently composed of 22 species (Fransen, 2015) distributed in the North Pacific Ocean, the North Atlantic Ocean, and the Arctic Ocean (Butler, 1980). The species are characterized by their distinctive bladed rostrums, possess two or more supraorbital spines, and have an exopod on the third maxilliped.

Examination of the stomach contents of a specimen of the Pacific cod, Gadus macrocephalus Tilesius, 1810 that was collected in the northern Gulf of Alaska revealed the presence of a fully intact, nearly undigested specimen of Spirontocaris truncata Rathbun, 1902, extending its distribution range approximately $1800 \mathrm{~km}$ to the north. It is the first record of this species in Alaskan waters. With the addition of this species, there are now 13 species of Spirontocaris recorded from Alaska (Drumm et al., in press). Material is deposited at the California Academy of Sciences (CASIZ). 

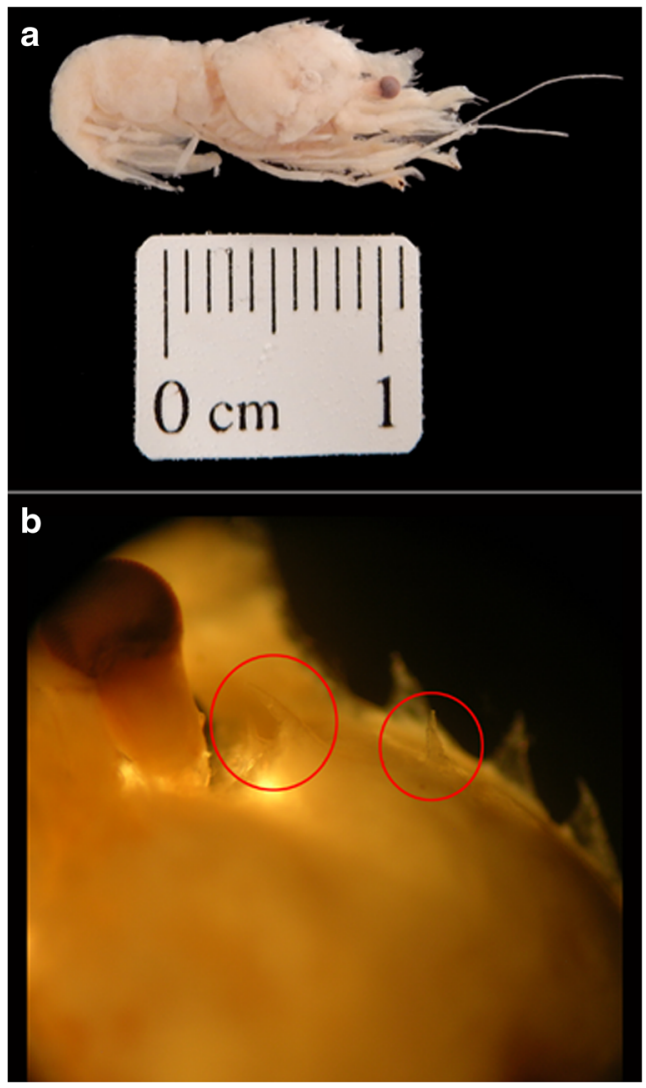

Fig. 1 a Spirontocaris truncata specimen (CASIZ 198280) found in the gut of Pacific cod in the northern Gulf of Alaska. $\mathbf{b}$ Detailed view of the head showing the three supraorbital spines (red circles)

\section{Systematics}

Order DECAPODA Latreille, 1802

Infraorder CARIDEA Dana, 1852

Superfamily ALPHEOIDEA Rafinesque, 1815

Family THORIDAE Kingsley, 1879

Spirontocaris truncata Rathbun, 1902

(Figure 1)

\section{Material examined}

One o $\left(58^{\circ} 35^{\prime} 30.408^{\prime \prime} \mathrm{N}, 148^{\circ} 37^{\prime} 19.668^{\prime \prime} \mathrm{W}\right)$ in the northern Gulf of Alaska (Fig. 2), carapace length $5.4 \mathrm{~mm}$, total length 22 mm, 150 m, 17 July 2011, CASIZ 198280.

\section{Distribution}

Type locality: Hecata Bank, Oregon, USA. Northern Gulf of Alaska (new record); Strait of Georgia, British Columbia to Baja California, Mexico, 37-92 m (Wicksten, 2012).

\section{Results and discussion}

The single specimen was identified using the key in Butler (1980). The three supraorbital spines are shown in Fig. 1b. The only other species that have three or more supraorbital spines are $S$. prionota (Stimpson, 1864) and $S$. pectinifera (Stimpson, 1860). Spirontocaris truncata can easily be distinguished from these two species by the shape of the rostrum. The lateral margins of the abdominal pleura in S. pectinifera are pectinate (Hayashi, 1977) and are smooth in S. truncata. The rostrum ventral spine count falls slightly outside the range given in Butler (1980). The specimen has 9 upper/6 lower,

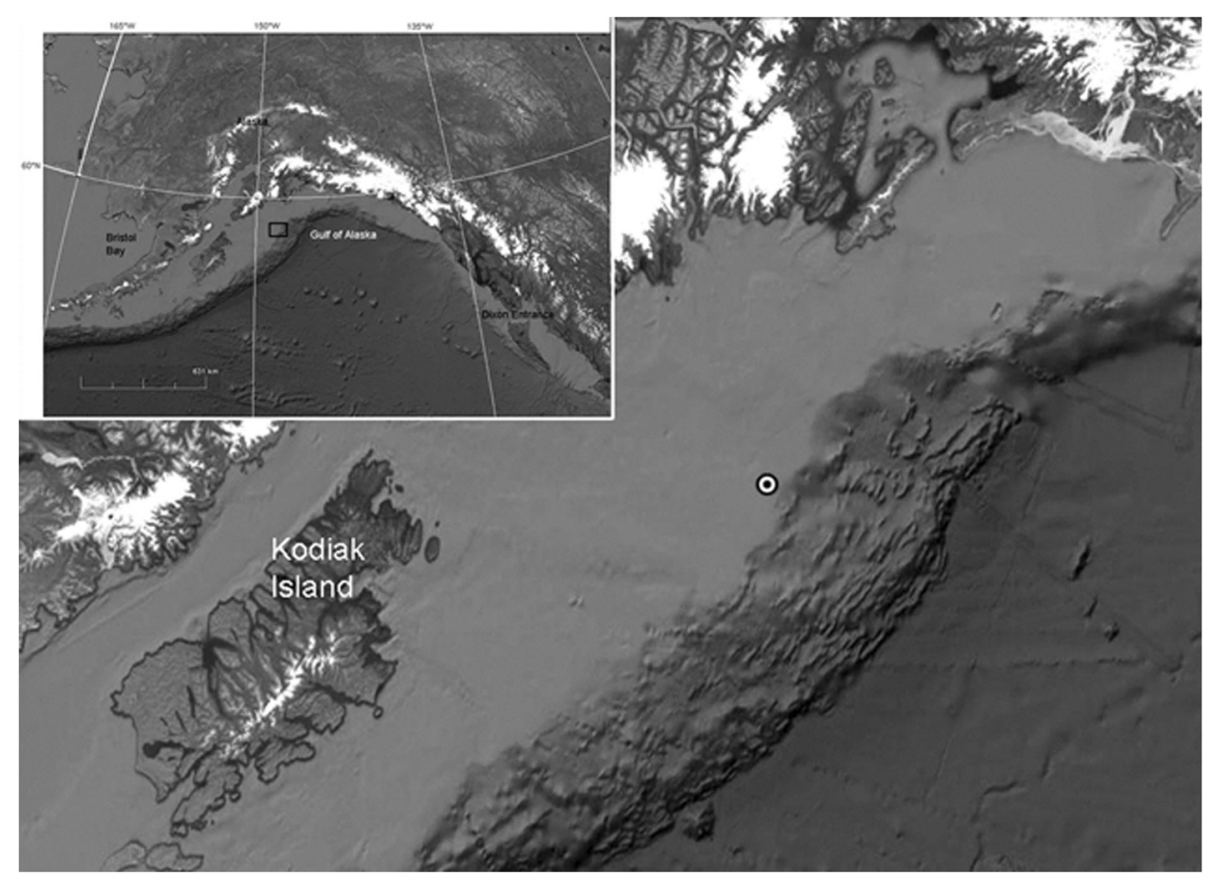

Fig. 2 Map showing collection site in the northern Gulf of Alaska (58³5'30.408"N, $\left.148^{\circ} 37^{\prime} 19.668^{\prime \prime} W\right)$ 
versus 7-9 upper/3-4 lower in Butler (1980). Determining whether this represents intraspecific variation or a putative new species will have to await further examination of more specimens.

We are confident that $S$. truncata truly occurs in the Gulf of Alaska, as the specimen was found to be fully intact and nearly undigested in the Pacific cod stomach, evidence of recent consumption. The capture locality was about $1200 \mathrm{~km}$ from Canadian waters. It is not surprising that this species has gone unnoticed in Alaskan waters until now, as all previous records have come from subtidal rocky reefs and banks (Wicksten, 2012) and all tows conducted by NMFS groundfish surveys are strategically placed to avoid rocky areas.

\section{Conclusions}

A large northward range extension was documented for the shrimp Spirontocaris truncata. A clear understanding of the distribution of marine species is a necessary prerequisite for effective monitoring and predictions about future changes to marine ecosystems.

\section{Acknowledgments}

We would like to thank Erika Acuna for collecting stomach samples and the captain and crew of the FN Ocean Explorer for their work in support of this effort. We also thank James Orr (NOAA) for reviewing an earlier draft of this manuscript.

\section{Authors' contributions}

DTD drafted the manuscript and SR collected and initially identified the shrimp species. Both authors read and approved the final manuscript.

\section{Competing interests}

The authors declare that they have no competing interests.

\section{Author details}

${ }^{1}$ EcoAnalysts, Inc.., 1420 S. Blaine Suite 14, Moscow, Idaho 83843, USA.

${ }^{2}$ University of Washington, School of Aquatic and Fishery Sciences, Box

355020, Seattle, WA 98195-5020, USA.

Received: 11 May 2016 Accepted: 3 June 2016

Published online: 18 July 2016

\section{References}

Butler TH. Shrimps of the Pacific coast of Canada. Canadian Bulletin of Fisheries and Aquatic Sciences. 1980;202:1-280.

De Grave S, Fransen CHJM. Carideorum catalogus: The recent species of the dendrobranchiate, stenopodidean, procarididean and caridean shrimps (Crustacea: Decapoda). Zoologische Mededelingen. 2011;85(9):195-589.

De Grave S, Li CP, Tsang LM, Chu KH, Chan T-Y. Unweaving hippolytoid systematics (Crustacea, Decapoda, Hippolytidae): resurrection of several families. Zoologica Scripta. 2014:43(5):496-507.

Drumm DT, Lauth RR, Clark RN, Orr JW. Northern range extensions and biological notes for three decapods in the eastern North Pacific. Crustaceana. 2013; 86(13-14):1572-85.

Drumm DT, Maslenikov KP, Van Syoc RJ, Orr JW, Lauth RR, Stevenson DE, Pietsch TW. (in press) An annotated checklist of the marine macroinvertebrates of Alaska. NOAA Professional Papers (NOAA, Seattle, WA).

Fransen C. Spirontocaris Spence Bate, 1888. Accessed through: World Register of Marine Species at http://www.marinespecies.org/aphia.php?p=taxdetails\& id=106994 on 2015-05-11. 2015

Gunderson DR, Sample TM. Distribution and abundance of rockfish off Washington, Oregon, and California during 1977. Marine Fisheries Review. 1980;42(3-4):2-16.
Hayashi Kl. Studies on the hippolytid shrimps from Japan-VI. The genus Spirontocaris Bate. Journal of the Shimonoseki University of Fisheries. 1977;25:155-86.

Pereyra WT, Reeves JE, Bakkala RG. Demersal fish and shellfish resources of the eastern Bering Sea in the baseline year 1975: distribution of crab resources from research surveys. NWAFC Processed Report. 1978; 62. (Northwest and Alaska Fisheries Science Center, National Marine Fisheries Service, NOAA, Seattle, WA).

von Szalay PG, Raring NW, Shaw FR, Wilkins ME, Martin MH. Data report: 2009 Gulf of Alaska bottom trawl survey. U.S. Department of Commerce, NOAA Technical Memo NMFS-AFSC-208. 2010; 245. (U.S. Department of Commerce, Washington, DC).

Wicksten MK. Decapod Crustacea of the Californian and Oregonian zoogeographic provinces. Zootaxa. 2012;3371:1-307.
Submit your next manuscript to BioMed Central and we will help you at every step:

- We accept pre-submission inquiries

- Our selector tool helps you to find the most relevant journal

- We provide round the clock customer support

- Convenient online submission

- Thorough peer review

- Inclusion in PubMed and all major indexing services

- Maximum visibility for your research

Submit your manuscript at www.biomedcentral.com/submit
Ciomed Central 